
S. Wellens, N.R. Brooks,
B. Thijs.
Dalton Transaction
43
$3443-3452$
(2014).

Cite this: DOI: 10.1039/c0xx00000x

PAPER

\title{
Carbene formation upon reactive dissolution of metal oxides in imidazolium ionic liquids
}

\author{
Sil Wellens, ${ }^{a, b}$ Neil R. Brooks, ${ }^{a}$ Ben Thijs, ${ }^{b}$ Luc Van Meervelt ${ }^{\mathrm{a}}$ and Koen Binnemans ${ }^{* a}$ \\ Received (in $X X X, X X X)$ Xth $X X X X X X X X X 20 X X$, Accepted Xth $X X X X X X X X X 20 X X$ \\ ${ }_{5}$ DOI: 10.1039/b000000x
}

Metal oxides were found to dissolve in different imidazolium ionic liquids with a hydrogen atom in the $\mathrm{C} 2$ position of the imidazolium ring, but not if a methyl substituent was present in the $\mathrm{C2}$ position. The crystal structure of the product that crystallised from an ionic liquid containing dissolved silver(I) oxide showed that this was a silver(I) carbene complex. The presence of carbenes ${ }_{10}$ in solution was proven by ${ }^{13} \mathrm{C}$ NMR spectroscopy and the reactions were also monitored by Raman spectroscopy. The dissolution of other metal oxides, namely copper(II) oxide, zinc(II) oxide and nickel(II) oxide was also studied in imidazolium ionic liquids and it was found that stable zinc(II) carbenes were formed in solution, but these did not crystallise under the given experimental conditions. A crystalline nickel(II) carbene complex could be obtained from a solution of nickel(II)

15 chloride dissolved in a mixture of 1-butyl-3-methylimidazolium and 1-ethyl-3-methylimidazolium acetate.

\section{Introduction}

Since metal oxides are insoluble in most organic solvents, the processing of metal oxides is currently done in aqueous 20 solutions. ${ }^{1 ; 2}$ Although water is generally considered as a green solvent, it must be realized that hydrometallurgical processing of metal oxide concentrates often requires large volumes of water and that large amounts of waste water are generated. Therefore there is an interest in alternative solvents for the processing of 25 metal oxides under ambient conditions. In the last decade a new class of solvents, namely ionic liquids (ILs), has been developed. Ionic liquids are solvents that consist entirely of ions. Many ionic liquids have a melting point below $100{ }^{\circ} \mathrm{C}$ and they have properties like a high thermal stability, a wide liquidus range, 30 nonvolatility and nonflammability. These solvents have shown the ability to dissolve a large variety of organic and inorganic compounds, including metal oxides. ${ }^{3-6}$ Ionometallurgy is the ionic liquid analogue of hydrometallurgy. ${ }^{7}$ Dai et al. were able to dissolve $\mathrm{UO}_{3}$ in imidazolium chloroaluminate ionic liquids. ${ }^{8}$ ${ }_{35}$ Billard and coworkers found that $\mathrm{UO}_{2}, \mathrm{UO}_{3}, \mathrm{Nd}_{2} \mathrm{O}_{3}, \mathrm{Eu}_{2} \mathrm{O}_{3}$ and $\operatorname{Pr}_{6} \mathrm{O}_{11}$ powders could be dissolved in the ionic liquid 1-methyl-3butyl-imidazolium bis(trifluoromethylsulfonyl)imide after addition of small amounts of nitric acid. ${ }^{9}$ Abbott and coworkers were able to dissolve a range of metal oxides in deep-eutectic 40 solvents (DES), which are mixtures of choline chloride with a hydrogen-bond donor (e.g. urea, ethylene glycol, carboxylic acids) that show similar properties to ionic liquids. ${ }^{10 ; 11}$ The functionalized ionic liquid betainium bis(trifluoromethylsulfonyl)imide showed selective solubility
45 towards a range of metal oxides. ${ }^{12 ; 13}$ The strongly bonded oxide anion is one of the problems associated with the digestion of the metal oxides in ionic liquids (or DES). The most straightforward method for digestion of a metal oxide in an ionic liquid is the addition of an acid which consumes the oxide anion with 50 formation of water:

$$
\mathrm{MO}_{\mathrm{y}}+2 \mathrm{y} \mathrm{HX} \rightarrow \mathrm{MX}_{2 \mathrm{y}}+\mathrm{y} \mathrm{H}_{2} \mathrm{O}
$$

Functionalized ionic liquids that contain acidic protons are able to 55 react with metal oxides and solvate the liberated metal ion in the solution. ${ }^{13}$ Ionic liquids with imidazolium cations are one of the more common types of ionic liquids, but they do not contain protons that can be easily released.

We have tested the suitability of imidazolium ionic liquids for ${ }_{60}$ the dissolution of selected metal oxides. In some cases, we found that metal oxides were soluble in these imidazolium ionic liquids and that the dissolution mechanism proceeded via proton exchange at the $\mathrm{C} 2$ position of the imidazolium ring to form water and an $N$-heterocyclic carbene (NHC). In particular, we 65 focused on the reaction with silver(I) oxide as it is already well known from work on homogeneous catalysts that silver can form $N$-heterocyclic carbenes. ${ }^{14-20}$ All literature reports on carbene formation make use of an organic solvent (e.g. dichloromethane, methanol) and not a pure ionic liquid. ${ }^{15 ; 21-23}$.

70 In this paper, the dissolution of silver(I) oxide in undiluted imidazolium ionic liquids with linear alkyl chains and with chloride, thiocyanate, acetate and dicyanamide anions is reported. Carbene formation has been found to be the driving force for the dissolution of silver(I) oxide. The reactivity of imidazolium ionic 
liquids was tested for dissolution of other metal oxides: copper(II) oxide, zinc(II) oxide and nickel(II) oxide. An overview of all chemical structures of the discussed ionic liquids, carbene complexes and other proposed compounds is presented in Figure 51 .

\section{Experimental}

\section{Instrumentation and methods}

${ }^{1} \mathrm{H}$ NMR and ${ }^{13} \mathrm{C}$ NMR spectra were recorded on a Bruker ${ }_{10}$ Avance 300 spectrometer, operating at $300 \mathrm{MHz}$ for ${ }^{1} \mathrm{H}$ and at 75 $\mathrm{MHz}$ for ${ }^{13} \mathrm{C}$. The samples were dissolved in DMSO- $d_{6}$ and the chemical shifts are given in ppm relative to tetramethylsilane (TMS). Elemental analyses (carbon, hydrogen and nitrogen) were obtained using a CE Instruments EA-1110 elemental analyser.

${ }_{15}$ ESI mass spectra were recorded on a Thermo Finnigan LCQ Advantage mass spectrometer. DSC traces were recorded in a helium atmosphere with a Mettler-Toledo DSC822e module with a heating/cooling rate of $10{ }^{\circ} \mathrm{C} / \mathrm{min}$. Indium was used as a standard for temperature and enthalpy calibrations. The IR 20 spectra were recorded in attenuated total reflectance mode on a Bruker Vertex 70 FTIR spectrometer at a resolution of $4 \mathrm{~cm}^{-1}$. Raman spectra were recorded with a Bruker Vertex Ram II spectrometer using $150 \mathrm{~mW}$ laser power (Nd-YAG; $1064 \mathrm{~nm}$ ) for 32 scans at a resolution of $4 \mathrm{~cm}^{-1}$.

${ }_{25}$ Crystals of complexes $\left[\mathrm{Ag}\left(\mathrm{C}_{2} \text { mim-ylide }\right)_{2}\right][\mathrm{SCN}],\left[\mathrm{Ag}\left(\mathrm{C}_{2}\right.\right.$ mimylide $\left.)_{2}\right][\mathrm{DCA}], \quad\left[\mathrm{Ag}\left(\mathrm{C}_{2} \text { mim-ylide }\right)_{2}\right][\mathrm{OAc}]$ and $\mathrm{Ni}\left(\mathrm{C}_{2} \mathrm{mim}-\right.$ ylide $)_{2}(\mathrm{OAc})_{2}$ suitable for single crystal X-ray diffraction were glued on a nylon loop attached to a copper pin and placed at room temperature on an Agilent SuperNova diffractometer using Mo ${ }_{30} \mathrm{~K} \alpha$ radiation $(\lambda=0.71073 \AA)$. The absorption corrections were applied using CrysAlisPro. ${ }^{24}$ All structures were solved using direct methods and refined by the full-matrix least-squares procedure in SHELXL. ${ }^{25}$ All hydrogen atoms were placed in calculated positions and refined using a riding model. In the 35 structure of $\left[\mathrm{Ag}\left(\mathrm{C}_{2} \text { mim-ylide }\right)_{2}\right][\mathrm{SCN}]$, due to the space group symmetry the SCN anion is disordered over two positions. Also the $\mathrm{H}$ atoms on the methyl group of the cation were disordered and modelled over two positions rotated by $60^{\circ}$ from each other. A summary of the crystallographic data can be found further in 40 the experimental section and Table 1 contains pertinent bond lengths, angles and geometrically values. CCDC-968222-968225 contains the supplementary crystallographic data for this paper. These data can be obtained free of charge from The Cambridge Crystallographic Data Center via 45 www.ccdc.cam.ac.uk/data_request/cif. The program OLEX2 was also used in refinement and making pictures of the structures. ${ }^{26}$ The metal contents in the ionic liquids were determined using a bench top total reflection X-ray fluorescence (TXRF) spectrometer (Picofox S2, Bruker). A certain mass of the ionic 50 liquid solution (approx. $0.1 \mathrm{~g}$ ) was dissolved in an aqueous $\mathrm{HCl}$ solution $(0.1 \mathrm{M}, 20 \mathrm{~mL})$. Gallium was added as an internal standard. A $5 \mu \mathrm{L}$ aliquot of the test solution was applied onto a quartz glass carrier, dried by evaporation in a hot air oven $\left(60^{\circ} \mathrm{C}\right)$ and measured with an exposure time of $400 \mathrm{~s}$.

55

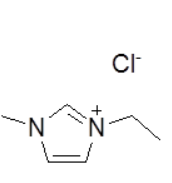

(a)

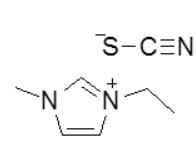

(b)

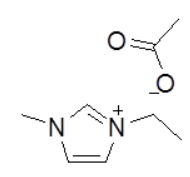

(c)

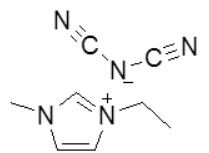

(d)

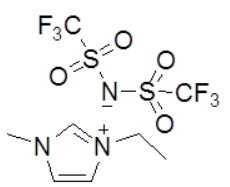

(e)

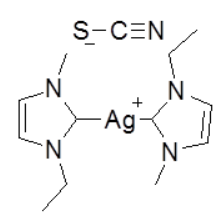

(f)<smiles></smiles>

(i)

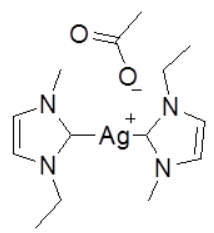

(g)<smiles>CCCCCCCC#N</smiles>

(j)<smiles>CCC1N(C)C=CN1[14CH2][14CH](C1N(C)C=CN1CC)N1C=CN(C)C1</smiles>

(h)<smiles>CCN1C=CN2C1C1C2N(OC(C)=O)N2C=CN(CC)C2N1OC(C)=O</smiles>

(k)

Figure 1: Overview of the chemical structures of the discussed compounds: (a) 1-ethyl-3-methylimidazolium chloride, (b) 1-ethyl-3-methylimidazolium thiocyanate, (c) 1-ethyl-3-methylimidazolium acetate, (d) 1-ethyl-3-methylimidazolium dicyanamide, (e) 1-ethyl-3-methylimidazolium bis(trifluoromethylsulfonyl)imide, (f) bis(1-ethyl-3-methylimidazol-2-ylidene)silver(I) thiocyanate, (g) bis(1-ethyl-3-methylimidazol-2-ylidene)silver(I) acetate, (h) bis(1-ethyl-3-methylimidazol-2-ylidene)silver(I) dicyanamide, (i) 1-ethyl-3-methylimidazolium dichloroargentate(I), (j) 1-ethyl-3methylimidazolium dithiocyanatoargentate(I), (k) bis(1-ethyl-3-methylimidazol-2-ylidene)nickel(II) acetate. 
$3 \mathrm{H}, \mathrm{CH}_{3}-\mathrm{CH}_{2}$ ), 1.51 (s, 3H, $\left.\mathrm{CH}_{3}-\mathrm{COO}\right), 3.84$ (s, 3H, N-CH $)$, 4.18 (q, 2H, $\left.\mathrm{CH}_{3}-\mathrm{CH}_{2}-\mathrm{N}\right), 7.50$ (d, 2H, CH-ar); $\delta_{\mathrm{c}}(75 \mathrm{MHz}$, DMSO- $\left.d_{6}\right)$ : 17.10, 26.21, 38.08, 45.89, 121.44, 123.00, 172, 179. ESI(+)MS calc. for $\mathrm{C}_{12} \mathrm{H}_{20} \mathrm{AgN}_{4}^{+}: \mathrm{m} / \mathrm{z}=327.1,329.1$; found: $\mathrm{m} / \mathrm{z}$ $5=326.9$ 328.8. CHN analysis: Calc. for $\mathrm{C}_{14} \mathrm{H}_{23} \mathrm{AgN}_{4} \mathrm{O}_{2}$ (387.23): C, 43.42; H, 5.99; N, 14.47. Found: C, 42.69; H, 7.03; N, 13.52. Melting point: $94{ }^{\circ} \mathrm{C}$. Crystal Data for $\mathrm{C}_{14} \mathrm{H}_{23} \mathrm{AgN}_{4} \mathrm{O}_{2}$ $(M=387.23)$ : colourless block $0.50 \times 0.15 \times 0.15 \mathrm{~mm}^{3}$, monoclinic, space group $C 2 / c$ (no. 15), $a=15.4432(7) \AA$, $b=$ 10 8.6443(4) $\AA, c=13.5597(6) \AA, \beta=108.450(5)^{\circ}, V=1717.13(13)$ $\AA^{3}, Z=4, T=294.4(3) \mathrm{K}, \mu(\mathrm{Mo} \mathrm{K} \alpha)=1.183 \mathrm{~mm}^{-1}, D_{\text {calc }}=$ $1.498 \mathrm{~g} / \mathrm{mm}^{3}, 3891$ reflections measured $\left(5.86 \leq 2 \Theta^{\circ} \leq 58.28\right)$, 1974 unique $\left(R_{\text {int }}=0.0127\right)$ which were used in all calculations. The final $R_{1}$ was $0.0237(>2 \sigma(\mathrm{I}))$ and $w R_{2}$ was 0.0643 (all data).

15

Procedure for the formation [bis(1-ethyl-3-methylimidazol-2ylidene)nickel(II)][acetate]:

After dissolution of anhydrous nickel(II) chloride (20 wt \%) in 1butyl-3-methylimdazolium acetate, an equal volume of 1-ethyl-320 methylimidazolium acetate layer was placed on top, by diffusion over time a few yellow crystals were formed. These crystals were harvested and used for the crystal structure determination, but it was impossible to characterise this compound in bulk. Crystal Data for $\mathrm{C}_{16} \mathrm{H}_{26} \mathrm{~N}_{4} \mathrm{NiO}_{4}(M=397.12)$ : yellow block $0.40 \times 0.10 \times$ ${ }_{25} 0.04 \mathrm{~mm}^{3}$, monoclinic, space group $C 2 / c$ (no. 15), $a=$ 12.4371(15) $\mathrm{A}, \quad b=9.8200(10) \AA, \quad c=15.9240(19) \AA, \quad \beta=$ 97.565(12) $)^{\circ}, V=1927.9(4) \AA^{3}, Z=4, T=293(2) \mathrm{K}, \mu($ Mo K $\alpha)=$ $1.033 \mathrm{~mm}^{-1}, D_{\text {calc }}=1.368 \mathrm{~g} / \mathrm{mm}^{3}, 4251$ reflections measured $(5.7$ $\leq 2 \Theta \leq 57.44), 2205$ unique $\left(R_{\text {int }}=0.0445\right)$ which were used in all 30 calculations. The final $R_{1}$ was $0.0632(>2 \sigma(\mathrm{I}))$ and $w R_{2}$ was 0.1954 (all data).

\section{Results and discussion:}

\section{Reactivity of silver(I) oxide with 1-ethyl-3-methylimidazolium 35 chloride.}

When 15 wt\% silver(I) oxide was added to the ionic liquid 1ethyl-3-methylimidazolium chloride, an instant vigorous reaction was observed and the oxide completely dissolved after about 2 hours at $90{ }^{\circ} \mathrm{C}$. However, virtually no solubility of silver(I) oxide 40 was found in other types of ionic liquids that were tested, such as quaternary ammonium ionic liquids. The dissolution reaction was monitored by ${ }^{13} \mathrm{C}$ NMR and the chemical shift of the carbon nucleus in the 2-position of the imidazolium ring shifted dramatically from about $136 \mathrm{ppm}$ in the pure ionic liquid to about $45179 \mathrm{ppm}$ on formation of a carbene (Figure 2). Also the resonances of all the other carbon nuclei in the compounds were shifted by 2 to $3 \mathrm{ppm}$, so it can be clearly seen in the ${ }^{13} \mathrm{C}$ spectra that the solution consists of a mixture of the starting ionic liquid and its carbene form.

50 Silver(I) carbene complexes have previously been reported especially as $N$-heterocyclic carbene catalysts. ${ }^{14-18 ; 27 ; 28}$ The carbene formation by reaction between 1-ethyl-3methylimidazolium chloride and silver(I) oxide is known. ${ }^{21 ; 29}$ However, the reaction has always been carried in a molecular 55 solvent, such as methanol or dichloromethane. This paper reports for the first time on reactions of silver(I) oxide in undiluted ionic liquids, which both act as solvent and reagent. Furthermore the reactions for different alkyl chain lengths and IL anions have been investigated.

60 Silver carbenes complexes with halide anions are known to be relatively stable against moisture and light. ${ }^{30}$ Reactions have even been carried out in water as solvent. ${ }^{31}$ The silver(I) carbene complexes in the chloride ionic liquids $\left[\mathrm{C}_{\mathrm{x}} \mathrm{mim}\right][\mathrm{Cl}]$ were found to be stable to moisture and light. No degradation of the solution 65 was observed over a period of several weeks.

\section{Influence of alkyl chain length}

The reaction between silver(I) oxide with other 1-alkyl-3methylimidazolium chloride ionic liquids $\left[\mathrm{C}_{\mathrm{x}} \mathrm{mim}\right][\mathrm{Cl}](\mathrm{x}=4,6$, $708,10)$ was also tested. Carbene formation could clearly be identified by ${ }^{13} \mathrm{C}$ NMR for all these ionic liquids, irrespective of the alkyl chain length. No crystals could directly be isolated from any of the ionic liquid solutions. In the literature, liquidcrystalline behaviour has been reported for silver(I) $\mathrm{N}$ 75 heterocyclic carbenes with imidazole moieties with longer alkyl chain lengths $\left[\mathrm{Ag}\left(\left(\mathrm{C}_{16} \mathrm{H}_{33}\right)_{2} \text { im-ylide }\right)_{2} \mathrm{Cl}\right]$ (im-ylide = imidazol-2ylidene) when it was mixed with the corresponding imidazolium salt $\left[\left(\mathrm{C}_{16} \mathrm{H}_{33}\right)_{2}\right.$ im-ylide- $\left.\mathrm{H}\right][\mathrm{Cl}]$ in a 1:1 ratio. ${ }^{15}$

\section{${ }_{80}$ Reactivity of silver(I) oxide with methyl substituted imidazolium at the $\mathrm{C}_{2}$ position.}

The solubility of silver(I) oxide in 1-butyl-3methylimidazolium chloride $\left[\mathrm{C}_{4} \mathrm{mim}\right][\mathrm{Cl}]$ was compared with its solubility in 1-butyl-2,3-dimethylimidazolium chloride $\left[\mathrm{C}_{4}-2,3\right.$ $85 \mathrm{dmim}][\mathrm{Cl}]$, in which the acidic hydrogen atom at the $\mathrm{C} 2$ position on the imidazolium ring is substituted by a methyl group. This substituent blocks the formation of an imidazolylidene carbene. However, an unexpected reaction of $\mathrm{Ag}_{2} \mathrm{O}$ with imidazolium methyl substituted at the $\mathrm{C} 2$ position to form silver $\mathrm{NHC}$ 90 complexes through oxidative cleavage of the $\mathrm{C}-\mathrm{C}$ bond has been reported. ${ }^{32}$ In the case of $\left[\mathrm{C}_{4} \mathrm{mim}\right][\mathrm{Cl}]$ a very good solubility of $\mathrm{Ag}_{2} \mathrm{O}$ was found, whereas in the case of $\left[\mathrm{C}_{4}-2,3-\mathrm{dmim}\right][\mathrm{Cl}]$ no reaction between $\mathrm{Ag}_{2} \mathrm{O}$ and the ionic liquid was observed. This confirms that carbene formation is proceeding by deprotonation 95 of the carbon atom in the $\mathrm{C} 2$ position. Therefore, the presence of a hydrogen atom on the $\mathrm{C} 2$ carbon atom of the imidazolium ring is a requirement for dissolution of silver(I) oxide in imidazolium ionic liquids.

\section{Reaction with imidazolium ionic liquids with other anions}

1-Ethyl-3-methylimidazolium ionic liquids with different anions were tested as reactive solvents for dissolution of silver(I) oxide: $\left[\mathrm{C}_{2} \mathrm{mim}\right][\mathrm{X}]$, where $\mathrm{X}=$ thiocyanate $\left(\mathrm{SCN}^{-}\right)$, dicyanamide $\left(\mathrm{DCA}^{-}\right)$, acetate $\left(\mathrm{OAc}^{-}\right)$or bis(trifluoromethylsulfonyl)imide $105\left(\mathrm{Tf}_{2} \mathrm{~N}^{-}\right)$was tested for the dissolution of silver(I) oxide. Silver(I) oxide was found to dissolve in $\left[\mathrm{C}_{2} \mathrm{mim}\right][\mathrm{SCN}],\left[\mathrm{C}_{2} \mathrm{mim}\right][\mathrm{DCA}]$ and $\left[\mathrm{C}_{2} \mathrm{mim}\right][\mathrm{OAc}]$, but not in $\left[\mathrm{C}_{2} \mathrm{mim}\right]\left[\mathrm{Tf}_{2} \mathrm{~N}\right]$. On cooling of the reaction mixtures, single crystals suitable for structure determination by $\mathrm{X}$-ray diffraction were obtained in ${ }_{110}\left[\mathrm{C}_{2} \mathrm{mim}\right][\mathrm{SCN}],\left[\mathrm{C}_{2} \mathrm{mim}\right][\mathrm{DCA}]$ and $\left[\mathrm{C}_{2} \mathrm{mim}\right][\mathrm{OAc}]$. The crystal structure determinations showed that compounds of formulae $\left[\mathrm{Ag}\left(\mathrm{C}_{2} \text { mim-ylide }\right)_{2}\right][\mathrm{SCN}]$ (Figure 3), $\left.\mathrm{Ag}\left(\mathrm{C}_{2} \text { mim-ylide }\right)_{2}\right][\mathrm{DCA}]$ (Figure 4) and $\left[\mathrm{Ag}\left(\mathrm{C}_{2} \text { mim-ylide }\right)_{2}\right][\mathrm{OAc}]$ (Figure 5) had been formed in the respective ionic liquids. All the crystal structures 115 belong to the monoclinic space group $C 2 / c$, but with different 


\section{Dalton Transactions}

\section{Cite this: DOI: $10.1039 / \mathrm{c0xx} 00000 x$}

PAPER

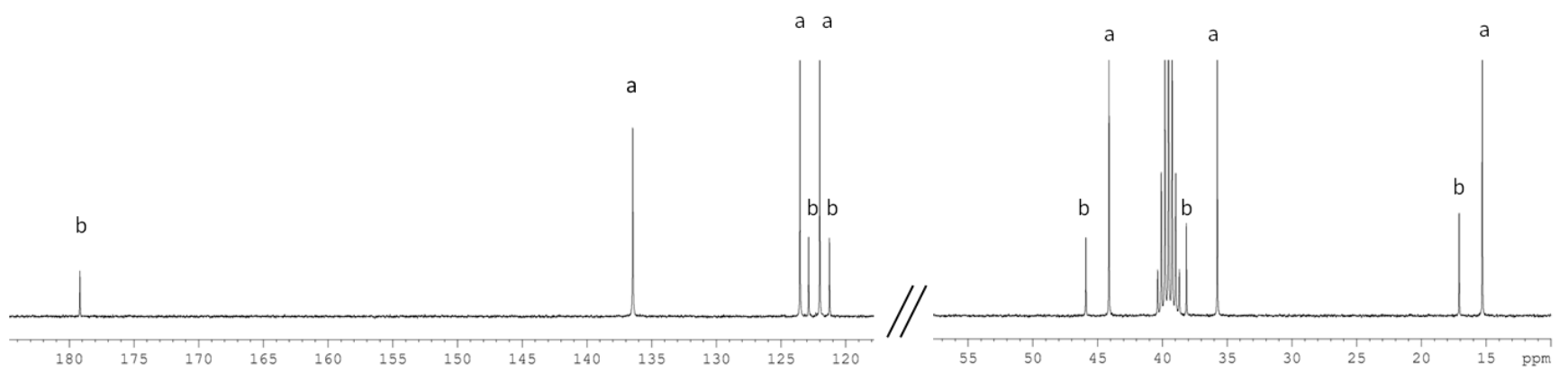

Figure 2: ${ }^{13} \mathrm{C}$ NMR spectrum of $\left[\mathrm{C}_{2} \mathrm{mim}\right][\mathrm{Cl}]$ after reaction with $15 \mathrm{wt} \%$ of $\mathrm{Ag}_{2} \mathrm{O}$. Resonances from $\left[\mathrm{C}_{2} \mathrm{mim}\right][\mathrm{Cl}]$ are labeled with a and resonances from the ylide with $\mathbf{b}$. The multiplet at $39.5 \mathrm{ppm}$ is from the DMSO- $d_{6}$ solvent.

5 unit cell parameters. A common feature is that the crystallographic asymmetric units contain one half of the cation and one half of the anion, with the remainder being generated by symmetry operations. The silver center have a linear or near linear two-coordinate silver(I) ion coordinated via the carbon in 10 the 2-position of the imidazolium ring of two ylides, wherein the $\mathrm{Ag}-\mathrm{C}$ bond lengths are in the expected ranges (Table 1). ${ }^{33}$ In $\left[\mathrm{Ag}\left(\mathrm{C}_{2} \text { mim-ylide }\right)_{2}\right][\mathrm{DCA}]$ the two planes created by the imidazole units are coplanar, but those in the other compounds are twisted with respect to each other (Table 1). All three 15 structures have the two ethyl groups of the coordinated $\mathrm{C}_{2}$ mimylide moieties on opposite side in a transoid conformation. The ethyl groups do not lie in the plane of the imidazolium moiety as shown by the $\mathrm{C} 2-\mathrm{N}-\mathrm{C}-\mathrm{C}$ torsion angles (Table 1 ). In contrast to the chloride-containing carbene complexes, it was observed for 20 the anions $[\mathrm{SCN}],[\mathrm{DCA}]$ and $[\mathrm{OAc}]$ that the ionic liquid solutions containing the silver(I) carbene complexes degraded by forming a black precipitate after period of several weeks exposed to air and light. However, this degradation was not observed during the first few days after synthesis. The isolated solid 25 products $\left[\mathrm{Ag}\left(\mathrm{C}_{2} \text { mim-ylide }\right)_{2}\right][\mathrm{X}]$ did not show any degradation over the period of several weeks exposed to air and light.

Table 1 Bond lengths, angles, torsions and plane-plane angles from the crystal structures of $\left[\mathrm{Ag}\left(\mathrm{C}_{2} \text { mim-ylide }\right)_{2}\right][\mathrm{DCA}],\left[\mathrm{Ag}\left(\mathrm{C}_{2} \mathrm{mim}-\right.\right.$ 30 ylide $\left.)_{2}\right][\mathrm{SCN}]$ and $\left[\mathrm{Ag}\left(\mathrm{C}_{2} \text { mim-ylide }\right)_{2}\right][\mathrm{OAc}]$.

\begin{tabular}{lccc}
\hline & {$[\mathrm{DCA}]$} & {$[\mathrm{SCN}]$} & {$[\mathrm{OAc}]$} \\
$\mathrm{Ag}-\mathrm{C} / \AA$ & $2.075(3)$ & $2.084(2)$ & $2.108(2)$ \\
$\mathrm{C}-\mathrm{Ag}-\mathrm{C} /{ }^{\circ}$ & $180.0(2)$ & $179.56(11)$ & $161.26(11)$ \\
$\mathrm{C}-\mathrm{N}-\mathrm{C}-\mathrm{C} /{ }^{\circ}$ & $91.2(5)$ & $-83.0(3)$ & $88.6(3)$ \\
plane-plane $^{\circ}$ & $0.0(3)$ & $55.09(7)$ & $53.32(6)$ \\
& & & \\
\hline
\end{tabular}

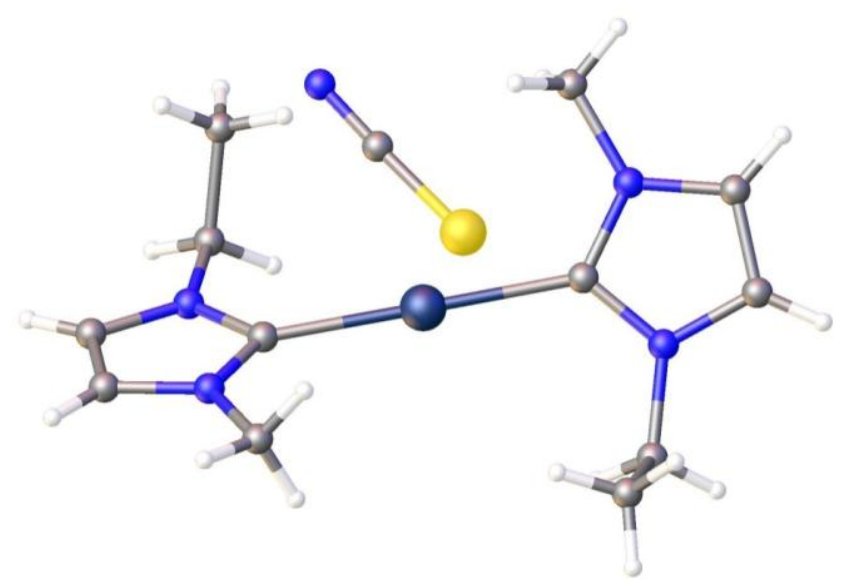

35 Figure 3 View of the crystal structure of [bis(1-ethyl-3-methylimidazol-2ylidene)silver(I)][thiocyanate]. The disorder of SCN anion and $\mathrm{H}$ atoms on the $\mathrm{CH}_{3}$ group is not shown.

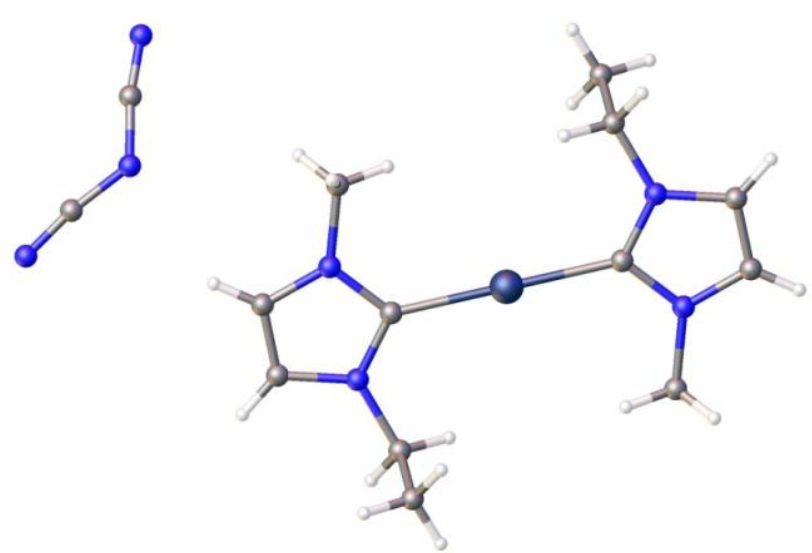

40 Figure 4: View of the crystal structure of [bis-(1-ethyl-3-methylimidazol2-ylidene)silver(I)][dicyanamide]. 


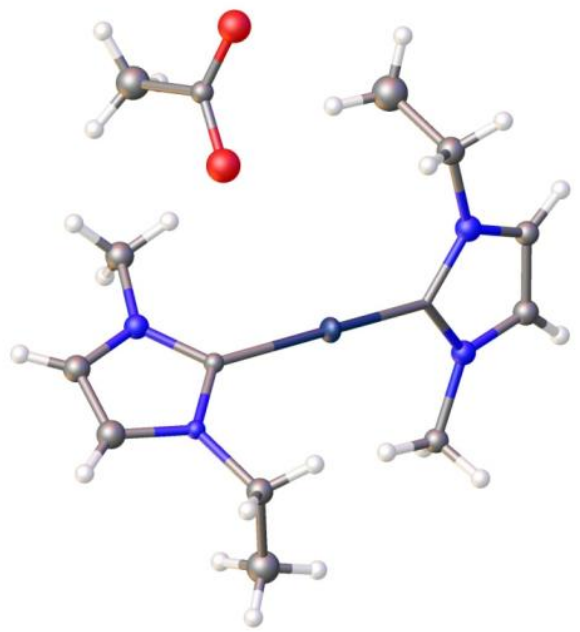

Figure 5: View of the crystal structure of [bis(1-ethyl-3-methylimidazol-2ylidene)silver(I)][acetate].

\section{Mechanism of Ag-NHC formation}

5 For stoichiometric reactions in molecular solvents between silver(I) oxide and imidazolium rings with short chains three main structures of silver carbenes have been reported. ${ }^{16 ; 17 ; 19 ; 20 ; 34}$ Namely, one where silver is linearly bonded to the halide and carbene $\left(\left(\mathrm{C}_{\mathrm{x}} \mathrm{C}_{\mathrm{x}} \mathrm{im}\right) \mathrm{AgX}\right)$, dimers with two bridging halides ${ }_{10}\left(\mathrm{C}_{\mathrm{x}} \mathrm{C}_{\mathrm{x}} \mathrm{im}\right)-\mathrm{Ag}-\left(\mu^{2} \mathrm{X}\right)_{2}-\mathrm{Ag}-\left(\mathrm{C}_{\mathrm{x}} \mathrm{C}_{\mathrm{x}} \mathrm{im}\right)$ and a cationic bis(imidazolylidene)silver(I) balanced with dihalogenoargentate anion $\left[\mathrm{Ag}\left(\mathrm{C}_{\mathrm{x}} \mathrm{C}_{\mathrm{x}} \text { im-ylide }\right)_{2}\right]^{+}\left[\mathrm{AgX} \mathrm{X}_{2}\right]^{-}$.

The reaction mechanism of the formation silver NHC complexes from silver(I) oxide has previously been extensively 15 investigated with density functional theory (DFT) computations by Hayes et al. ${ }^{34}$ More in particular they investigated the reaction mechanism between silver(I) oxide and two 1,3dimethylimidazolium iodide moieties $\left[\mathrm{C}_{1} \mathrm{mim}\right][\mathrm{I}]$ in dichloromethane with the formation of two $\left(C_{1}\right.$ mim-ylide $) \mathrm{AgX}$ 20 compounds. In their reaction mechanism, the authors proposed that first an exergonic deprotonation step occurs which is driven by the strong basicity of the $\mathrm{Ag}_{2} \mathrm{O}$ and this step is then followed by an exergonic metalation, with only a low energy barrier for which the transition state is stabilized by a second imidazolium 25 cation. The products formed at this intermediate step are $\mathrm{AgOH}$ and $\left(\mathrm{C}_{1}\right.$ mim-ylide $) \mathrm{AgI}$, but with the ' $\mathrm{AgOH}$ ' stabilised by interactions to the new ylide complex (equation 2). The next step is a second deprotonation in which silver(I) hydroxide abstracts the proton of a second imidazolium cation and a second 30 metalation step now without an imidazolium assisting the reaction forming a second $\left(\mathrm{C}_{1}\right.$ mim-ylide $)$-Ag-I complex (equation 3). The overall reaction is given by equation 4 .

$\mathrm{Ag}_{2} \mathrm{O}+\left[\mathrm{C}_{1}\right.$ mim $][\mathrm{I}] \rightarrow \mathrm{AgOH}+\left(\mathrm{C}_{1}\right.$ mim-ylide $) \mathrm{AgI}$

${ }_{35} \mathrm{AgOH}+\left[\mathrm{C}_{1} \mathrm{mim}\right][\mathrm{I}] \rightarrow \mathrm{H}_{2} \mathrm{O}+\left(\mathrm{C}_{1}\right.$ mim-ylide $) \mathrm{AgI}$

$\mathrm{Ag}_{2} \mathrm{O}+2\left[\mathrm{C}_{1}\right.$ mim $][\mathrm{I}] \rightarrow 2\left[\left(\mathrm{C}_{1}\right.\right.$ mim-ylide $\left.) \mathrm{AgI}\right]+\mathrm{H}_{2} \mathrm{O}$

To achieve the final product with two carbenes coordinated to the same $\mathrm{Ag}$ center $\left(\left[\mathrm{Ag}\left(\mathrm{C}_{\mathrm{x}} \mathrm{C}_{\mathrm{x}} \text { im-ylide }\right)_{2}\right]^{+}\right)$a rearrangement reaction 40 is required (reaction 5 ).

$2\left[\left(\mathrm{C}_{\mathrm{x}} \mathrm{C}_{\mathrm{x}}\right.\right.$ im-ylide $\left.) \mathrm{AgX}\right] \leftrightarrows\left[\mathrm{Ag}\left(\mathrm{C}_{\mathrm{x}} \mathrm{C}_{\mathrm{x}} \text { im-ylide }\right)_{2}\right]^{+}\left[\mathrm{AgX}{ }_{2}\right]$
This equilibrium is known to exist and has been extensively 45 reviewed by Lin et al. ${ }^{17}$ In ionic liquid solvents, the equilibrium is likely to lie to the right hand side due to the ionic nature of the solvent and products.

However, one has to be aware that that reactions in ionic liquids can follow different pathways than in molecular 50 solvents. ${ }^{35-37}$ Whilst dichloromethane is a somewhat polar solvent, the ionic nature of the ionic liquid solvents may favour more ionic intermediates so species like $\left[\left(\mathrm{C}_{\mathrm{x}} \mathrm{C}_{\mathrm{x}}\right.\right.$ im-ylide $\left.) \mathrm{AgX}\right]$ may not get formed at all. We propose that in the case of the $\left[\mathrm{C}_{\mathrm{x}} \mathrm{mim}\right][\mathrm{X}]$ compounds studied here as pure ionic liquids, the 55 process begins with the same barrier-less and exergonic deprotonation step, followed by a low barrier and exergonic metalation to form a complex of formation $\left[\left(\mathrm{C}_{\mathrm{x}} \mathrm{mim}-\right.\right.$ ylide) $\left.\mathrm{AgXAgOH} \cdots\left(\mathrm{C}_{\mathrm{x}} \mathrm{mim}\right)\right][\mathrm{X}]$ (Scheme 1$)$. This complex that acts as the base and deprotonates the second imidazolium moiety 60 and then metallation occurs by the silver center that is already coordinated by the carbene leading to a $\left[\mathrm{Ag}\left(\mathrm{C}_{\mathrm{x}} \text { mim-ylide }\right)_{2}\right]$ cation, a $\left[\mathrm{Ag}_{2} \mathrm{X}\right]^{-}$anion and a molecule of water (Scheme 1) rather than two molecules of $\left[\left(\mathrm{C}_{\mathrm{x}} \mathrm{C}_{\mathrm{x}} \mathrm{im}-\mathrm{ylide}\right) \mathrm{AgX}\right]$ proposed by Hayes et al. ${ }^{34}$ The highly ionic nature of the ionic liquid would ${ }_{65}$ favour the formation of two ionic species over the formation of two separate neutral $\left[\left(\mathrm{C}_{\mathrm{x}}\right.\right.$ mim-ylide $\left.) \mathrm{AgX}\right]$ complexes. $^{35-37}$

The solid products isolated in the cases of $\left[\mathrm{Ag}\left(\mathrm{C}_{\mathrm{x}} \mathrm{mim}-\right.\right.$ ylide $\left.)_{2}\right][\mathrm{X}]([\mathrm{X}]=[\mathrm{SCN}],[\mathrm{DCA}]$ and $[\mathrm{OAc}])$ are formed by anion exchange of the formed $\left[\mathrm{Ag}\left(\mathrm{C}_{\mathrm{x}} \text { mim-ylide }\right)_{2}\right]^{+}[\mathrm{AgX}]^{-}$ 70 complex and the ionic liquid giving the following as overall reaction scheme:

$$
\begin{aligned}
& \mathrm{Ag}_{2} \mathrm{O}+3\left[\mathrm{C}_{2} \text { mim }\right][\mathrm{X}] \\
& {\left[\mathrm{C}_{2} \mathrm{mim}\right]\left[\mathrm{Ag}(\mathrm{X})_{2}\right]_{(\text {dissolved) }}}
\end{aligned} \rightarrow\left[\mathrm{Ag}\left(\mathrm{C}_{2} \text { mim-ylide }\right)_{2}\right][\mathrm{X}]_{(\mathrm{s})}+\underset{(6)}{\mathrm{H}_{2} \mathrm{O}}+
$$

75

The formation of the $\left[\mathrm{AgX}_{2}\right]^{-}$anion was shown by speciation studies of the silver(I) complexes in $\left[\mathrm{C}_{\mathrm{x}} \mathrm{mim}\right][\mathrm{SCN}]$ investigated by in-situ Raman spectroscopy. The shift in the $v_{\mathrm{C} \equiv \mathrm{N}}$ stretching vibration of the $[\mathrm{SCN}]$ anion is very indicative of the 80 coordinating nature of the anion. The spectra of the homogeneous solutions, the neat ionic liquid and the crystal are shown in Figure 6. The stretching vibration $v_{\mathrm{C} \equiv \mathrm{N}}$ of pure $\left[\mathrm{C}_{2} \operatorname{mim}\right][\mathrm{SCN}]$ at 2055 $\mathrm{cm}^{-1}$ is partly shifted to $2080 \mathrm{~cm}^{-1}$ in the silver-containing $\left[\mathrm{C}_{2} \mathrm{mim}\right][\mathrm{SCN}]$ solution, which indicates coordination of the 85 thiocyanate anion to the $\mathrm{Ag}^{+}$ion. A linear $\left[\mathrm{Ag}(\mathrm{SCN})_{2}\right]$ anion is the most probable product as the new peak corresponds with the $v_{\mathrm{C} \equiv \mathrm{N}}$ of the $\left[\mathrm{Ag}(\mathrm{SCN})_{2}\right]^{-}$complex observed in other non-aqueous solvents. $^{38}$ The Raman spectrum of the filtrate, after crystallisation of the $\left[\mathrm{Ag}\left(\mathrm{C}_{2} \text { mim-ylide }\right)_{2}\right][\mathrm{SCN}]$, shows the 90 absorption band of the coordinated thiocyanate anions was intensified compared to that of the uncoordinated thiocyanate anion due to the depletion of thiocyanate anions from the solution by precipitation as the $\left[\mathrm{Ag}\left(\mathrm{C}_{2} \text { mim-ylide }\right)_{2}\right][\mathrm{SCN}]$ complex and so a net increase of the $\left[\mathrm{Ag}(\mathrm{SCN})_{2}\right]^{-}$anion is observed. ${ }^{39 ; 40}$ The 95 spectrum of the pure $\left[\mathrm{Ag}\left(\mathrm{C}_{2} \text { mim-ylide }\right)_{2}\right][\mathrm{SCN}]$ shows a peak at $2061 \mathrm{~cm}^{-1}$ indicating the presence of non-coordinating thiocyanate groups. This peak is slightly shifted compared to pure $\left[\mathrm{C}_{2} \mathrm{mim}\right][\mathrm{SCN}]$ due to the former being in the solid state and the latter in the liquid state. 


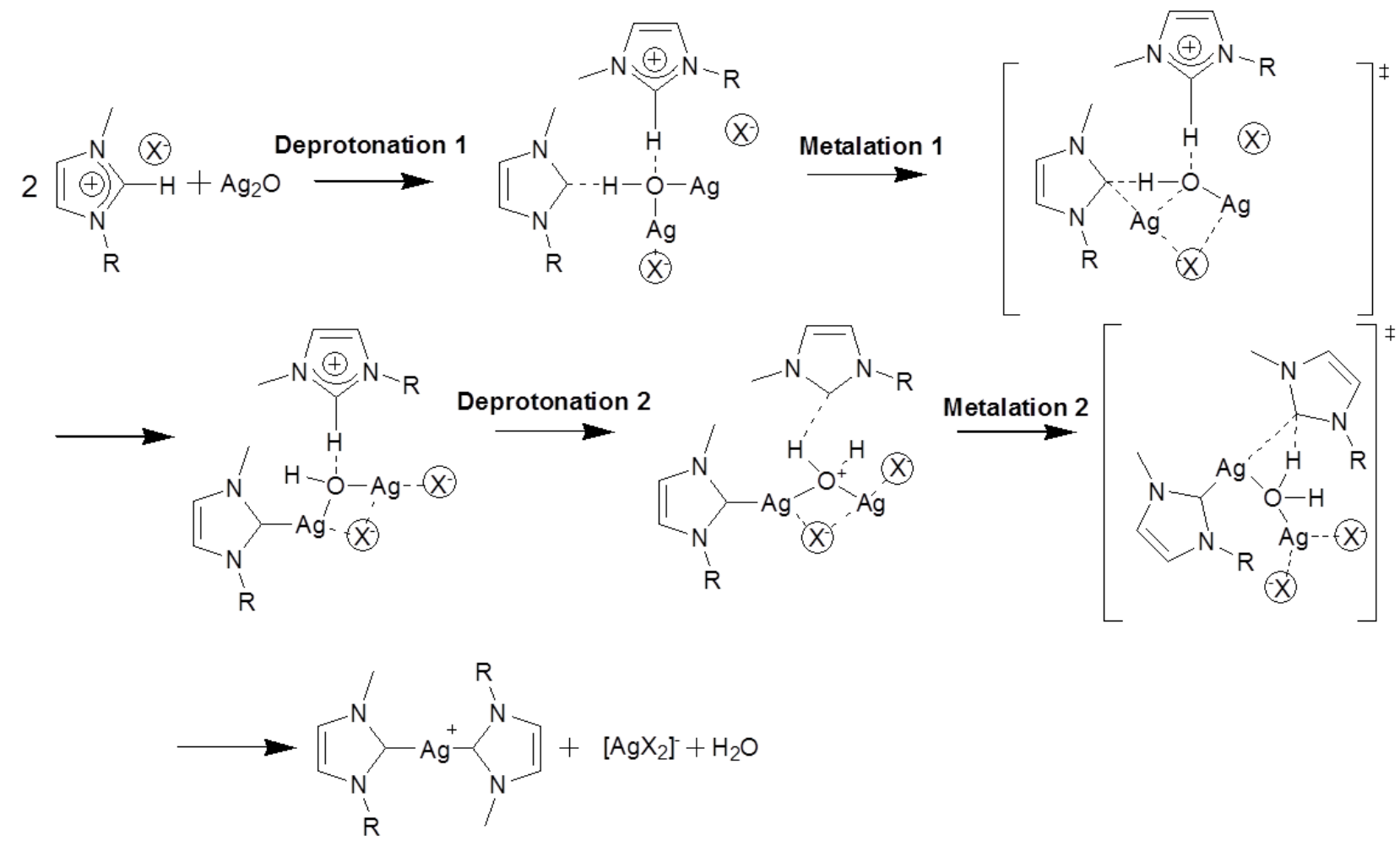

Scheme 1: Proposed mechanism for the reaction between $\mathrm{Ag}_{2} \mathrm{O}$ and imidazolium ionic liquids of the type $\left[\mathrm{C}_{x} \mathrm{mim}\right][\mathrm{X}]\left(\text { with } \mathrm{X}=\mathrm{Cl}^{-}, \mathrm{SCN}^{-}, \mathrm{DCA} \mathrm{A}^{-} \text {or } \mathrm{OAc}\right)^{-}$).

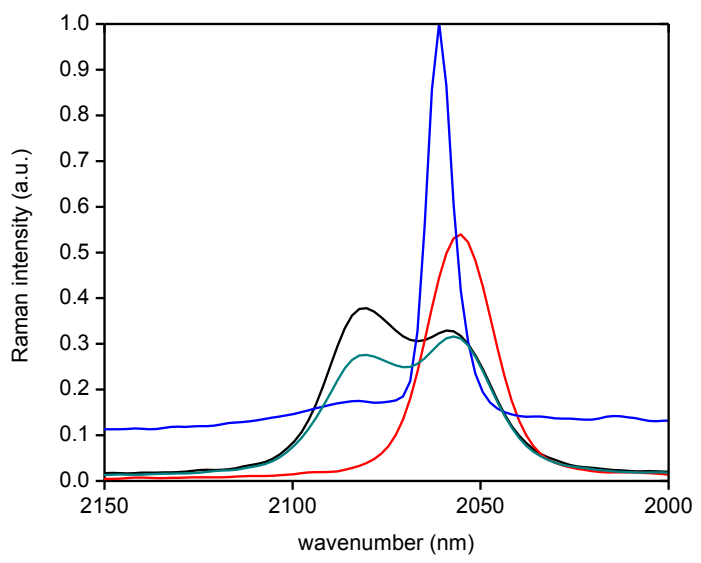

Figure 6: Raman spectra between 2150 and $2000 \mathrm{~cm}^{-1}$ of $\left[\mathrm{C}_{2} \mathrm{mim}\right][\mathrm{SCN}]$ 5 (red), $\left[\left(\mathrm{C}_{2} \text { mim-ylide }\right)_{2} \mathrm{Ag}\right][\mathrm{SCN}]$ (blue), $\mathrm{Ag}(\mathrm{I})$-containing-[ $\mathrm{C}_{2}$ mim] $[\mathrm{SCN}]-$ solution (green) and the filtrate (black).

The dissolution of silver(I) oxide in $\left[\mathrm{C}_{2} \mathrm{mim}\right][\mathrm{X}],(\mathrm{X}=\mathrm{SCN}$, DCA or OAc) also occurred at room temperature, but the reactions were slower, because the ionic liquids have a much 10 higher viscosity compared to molecular solvents, especially at room temperature. At elevated temperatures the viscosity is lower and there is more energy to overcome the energy barriers of the reaction.

The fact that silver(I) oxide does not react with $\left[\mathrm{C}_{2} \mathrm{mim}\right]\left[\mathrm{NTf}_{2}\right]$ 15 in the ionic liquid solution but does react when performed in a molecular solvent is puzzling. ${ }^{23}$ Looking at the reaction mechanism, the first deprotonation step requires the transformation of solid $\mathrm{Ag}_{2} \mathrm{O}$ into an intermediate $\mathrm{Ag}(\mathrm{OH}) \mathrm{Ag}$ species that is brought into solution and stabilised by a hydrogen20 bond with the formed carbene, a free imidazolium moiety and Ag-anion interactions (Scheme 1). With $\left[\mathrm{NTf}_{2}\right]^{-}$having the least coordinating ability of the anions studied, it is reasonable to propose that the $\left[\mathrm{NTf}_{2}\right]^{-}$anion cannot stabilise the $\left[\left(\mathrm{C}_{\mathrm{x}} \mathrm{mim}-\right.\right.$ ylide) $\left.\mathrm{AgXAgOH} \cdots\left(\mathrm{C}_{\mathrm{x}} \mathrm{mim}\right)[\mathrm{X}]\right]$ intermediate without the 25 additional solvation effects of a molecular solvent.

\section{Reactivity of $\mathrm{ZnO}, \mathrm{NiO}$ and $\mathrm{CuO}$ in imidazolium ionic liquids}

Other metal oxides were tested for their reactivity in imidazolium ionic liquids, in particular $\mathrm{CuO}, \mathrm{NiO}$ and $\mathrm{ZnO}$ in ${ }_{30}\left[\mathrm{C}_{2} \mathrm{mim}\right][\mathrm{X}](\mathrm{X}=\mathrm{Cl}, \mathrm{OAc})$. Table 2 reports the amount of the metal oxides that could be dissolved in the ionic liquid and shows that both $\mathrm{CuO}$ and $\mathrm{ZnO}$ show are appreciable solubility in $\left[\mathrm{C}_{2} \mathrm{mim}\right][\mathrm{Cl}]$, whereas only $\mathrm{ZnO}$ is well soluble in 
$\left[\mathrm{C}_{2} \mathrm{mim}\right][\mathrm{OAc}]$. $\mathrm{NiO}$ is slightly soluble in $\left[\mathrm{C}_{2} \mathrm{mim}\right][\mathrm{Cl}]$, but only poorly soluble in $\left[\mathrm{C}_{2} \mathrm{mim}\right][\mathrm{OAc}]$.

In the case of $\mathrm{ZnO}$, the dissolution product could be investigated by ${ }^{13} \mathrm{C}$ NMR spectroscopy since $\mathrm{Zn}^{2+}$ is a 5 diamagnetic ion. The undissolved material was filtered off from the solution and the ${ }^{13} \mathrm{C}$ NMR spectra recorded in DMSO- $d_{6}$. Carbene formation was observed in both the chloride and acetate imidazolium ionic liquid, as indicated by the large shift of the carbon nucleus in the $\mathrm{C} 2$ position of the imidazole ring (Figure $107)$. However, in contrast to the spectra recorded from the silver(I) ylides, two peaks appeared in the carbene region. In $\left[\mathrm{C}_{2} \mathrm{mim}\right][\mathrm{OAc}]$, these peaks were at 175.1 and $174.2 \mathrm{ppm}$ with an approximate relative intensity ratio of 2:1 (Figure 7 (bottom); the resonance of the $\mathrm{COO}^{-}$group of the $\mathrm{OAc}$ anion at $173.9 \mathrm{ppm}$ also 15 appears in this region). The same intensity ratio was also found in $\left[\mathrm{C}_{2} \mathrm{mim}\right][\mathrm{Cl}]$ with the resonances at 173.2 and $172.8 \mathrm{ppm}$ (Figure 7 (top)). Also, the chemical shifts of all the other carbon nuclei in the spectrum showed two new small peaks due to the ylide formation, shifted by 2 to $3 \mathrm{ppm}$ relative to the parent 20 imidazolium nuclei. The formation of two new peaks with a 2:1 ratio is also seen in the ${ }^{1} \mathrm{H}$ NMR spectrum. The fact that two new peaks appear (instead of one as for the silver complex) can possibly be ascribed to two different coordination environments around the $\mathrm{Zn}^{2+}$ ion. For instance, zinc(II) could be coordinated 25 as $\left[\mathrm{Zn}\left(\mathrm{C}_{2} \text { mim-ylide }\right)_{2} \mathrm{X}_{2}\right]$ or as $\left[\mathrm{Zn}\left(\mathrm{C}_{2} \text { mim-ylide }\right) \mathrm{X}_{3}\right]^{-}$. Unfortunately no crystals could be isolated from the solution for further investigation of the structure of the carbene complexes.

Previous reports on zinc ylides with $N$-heterocyclic carbenes are rare as reported in a recent review article by Budagumpi et
$30 \mathrm{al.}^{41}$ One example is the 1-butyl-3-methylimidazolylidene zinc complex $\left[\mathrm{ZnBr}_{2}\left(\mathrm{C}_{4} \text { mim-ylidene }\right)_{2}\right]$ which was directly synthesized from the corresponding ionic liquid $\left[\mathrm{C}_{4} \mathrm{mim}\right] \mathrm{Br}$ using diethyl zinc $\left(\mathrm{ZnEt}_{2}\right) .{ }^{42}$ In contrast to $\mathrm{ZnEt}_{2}$ which must be handled in moisture-free environments, we show that zinc carbenes 35 complexes can be formed starting from $\mathrm{ZnO}$ and that zinc carbenes are relatively stable in non-dried ionic liquid solution.

The solutions formed by dissolution of copper(II) oxide and nickel(II) oxide in the imidazolium ionic liquids could not be investigated by ${ }^{13} \mathrm{C} \mathrm{NMR}$, because of their paramagnetic 40 behaviour.

Table 2: Dissolution of $\mathrm{CuO}, \mathrm{NiO}$ and $\mathrm{ZnO}$ in $\left[\mathrm{C}_{2} \mathrm{mim}\right][\mathrm{Cl}]$ and $\left[\mathrm{C}_{2} \mathrm{mim}\right][\mathrm{OAc}]$ at $90{ }^{\circ} \mathrm{C}$ reported as $\mathrm{mg}(\mathrm{MO}) / \mathrm{g}(\mathrm{IL})$.

$\begin{array}{ccc} & {\left[\mathrm{C}_{2} \text { mim }\right][\mathrm{Cl}]} & {\left[\mathrm{C}_{2} \text { mim }\right][\mathrm{OAc}]} \\ \mathrm{CuO} & 64 & 2.3 \\ \mathrm{NiO} & 5 & 0.9 \\ \mathrm{ZnO} & 36 & 83\end{array}$

45

In a related study, but using $\mathrm{NiCl}_{2}$ as nickel source instead of $\mathrm{NiO}$, crystals of a nickel carbene complex were isolated. $20 \mathrm{wt} \%$ of $\mathrm{NiCl}_{2}$ could be dissolved in $\left[\mathrm{C}_{4} \mathrm{mim}\right][\mathrm{OAc}]$. However in the case of $\left[\mathrm{C}_{2} \mathrm{mim}\right][\mathrm{OAc}]$ when $15 \mathrm{wt} \% \mathrm{NiCl}_{2}$ was dissolved at 90 ${ }_{50}^{\circ} \mathrm{C}$, a yellow amorphous solid was found to precipitate, although an appreciable amount of $\mathrm{Ni}^{2+}$ stayed dissolved in the solution

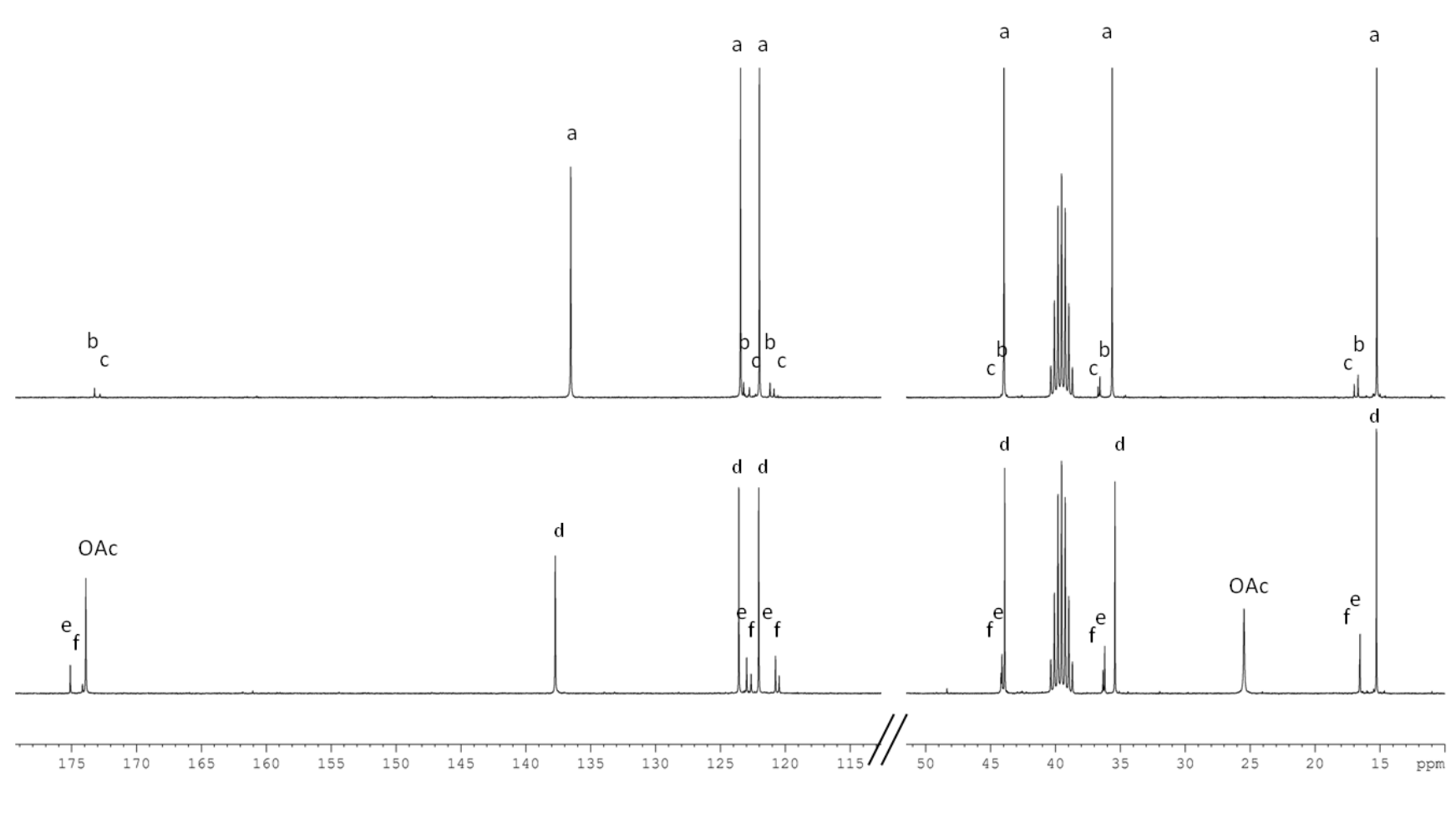

Figure 7: ${ }^{13} \mathrm{C}$ NMR spectra showing carbene formation upon addition of $\mathrm{ZnO}$ to $\left[\mathrm{C}_{2} \mathrm{mim}\right][\mathrm{Cl}]$ (top) (peaks from $\left[\mathrm{C}_{2} \mathrm{mim}\right][\mathrm{Cl}]$ indicated 55 with $\mathbf{a}$ and peaks from the ylide with $\mathbf{b}$ and $\mathbf{c}$; and to $\left[\mathrm{C}_{2} \mathrm{mim}\right][\mathrm{OAc}]$ (bottom). Peaks from $\left[\mathrm{C}_{2} \text { mim }\right]^{+}$indicated with $\mathbf{d}$ and peaks from the ylide with $\mathbf{e}$ and $\mathbf{f}$ ). 


\section{Cite this: DOI: $10.1039 / \mathrm{c} 0 x \times 00000 x$}

(82 $\mathrm{mg} / \mathrm{g}$ ). Characterization of the species formed in the solid and liquid states proved difficult so a crystallisation experiment was devised to slowly introduce $\left[\mathrm{C}_{2} \mathrm{mim}\right][\mathrm{OAc}]$ by way of layering into the $20 \mathrm{wt} \% \mathrm{NiCl}_{2}$ solution in $\left[\mathrm{C}_{4} \mathrm{mim}\right][\mathrm{OAc}]$. After 5 several days, small yellow crystals appeared in the solution and these were characterised by single crystal X-ray diffraction and found to be a nickel(II) $N$-heterocyclic carbene complex of formula $\left[\mathrm{Ni}\left(\mathrm{C}_{2} \text { mim-ylide }\right)_{2}\right][\mathrm{OAc}]_{2}$. Although, several crystals were formed it was not possible to isolate a bulk sample so that 10 no bulk analysis results are available.

Nickel(II) $N$-heterocyclic carbene compounds are relatively common, but most of these compounds have large substituents such as diisopropyl on the imidazolium rings, as seen, for example, in diiodo bis(1,3-diisopropylimidazol-2-ylidene) 15 nickel(II). ${ }^{43}$ These authors also report $N$-heterocyclic carbenes with less bulky substituents such as diiodo bis(1-methyl-3propylimidazol-2-ylidene) nickel(II). ${ }^{43}$ There exist no literature reports about nickel(II) $N$-heterocyclic carbene compounds with acetate ligands, ${ }^{33}$ although $\mathrm{Ni}(\mathrm{OAc})_{2}$ is quite frequently used as a 20 starting material in these syntheses. ${ }^{43-45}$ The formation of carbenes in acetate ionic liquids has been studied by other research groups and the $\mathrm{H}$-atom at the $\mathrm{C} 2$ position of the imidazolium ring is known to be exchangeable and could protonate the acetate anion, so that the $\left[\mathrm{C}_{2} \mathrm{mim}\right]^{+}$cation and the 25 acetate anion are in equilibrium with the carbene and acetic acid. $^{35 ; 46}$ In the case of $\left[\mathrm{Ni}\left(\mathrm{C}_{2} \text { mim-ylide }\right)_{2}\right][\mathrm{OAc}]_{2}$, the carbene forms a complex with the $\mathrm{Ni}^{2+}$ ion and then precipitates from the solution.

The structure of the $\left[\mathrm{Ni}\left(\mathrm{C}_{2} \text { mim-ylide }\right)_{2}\right][\mathrm{OAc}]_{2}$ crystals was 30 collected in air at room temperature, showing their relative stability, and was found to be in monoclinic space group $C 2 / c$ with the complex lying on a crystallographic two-fold axis. The nickel centers are square planar with the two ylides and the two acetate ligands cis to each other (Figure 8).

${ }_{35}$ This cis orientation of two ylides has only been seen before in bis(1,3-di-isopropylimidazol-2-ylidene)bis(phenylsilyl)nickel(II) and bis(1,3-diisopropylimidazol-2ylidene)hydrido(methyl(diphenyl)silyl)nickel(II), ${ }^{47}$ whereas the trans configuration is much more prevalent, ${ }^{33}$ for example in the 40 dihalides mentioned above. ${ }^{43}$ The bond lengths $(\mathrm{Ni}-\mathrm{C}=1.865(4)$ $\AA, \mathrm{Ni}-\mathrm{O}=1.926(3) \AA)$ and bond angles $\left(\mathrm{C}-\mathrm{Ni}-\mathrm{C}=91.9(2)^{\circ}\right.$, O$\left.\mathrm{Ni}-\mathrm{O}=89.80(19)^{\circ}, \mathrm{C}-\mathrm{Ni}-\mathrm{O}=89.15(17), 178.41(15)^{\circ}\right)$ are within expectations. The two ylides are twisted by $88.58(15)^{\circ}$ with respect to each other which allows them to occupy cis

45 coordination sites and the ethyl groups are out of the plane of the imidazolylidene rings $\left(\mathrm{C} 2-\mathrm{N}-\mathrm{C}-\mathrm{C}=117.2(6)^{\circ}\right)$.

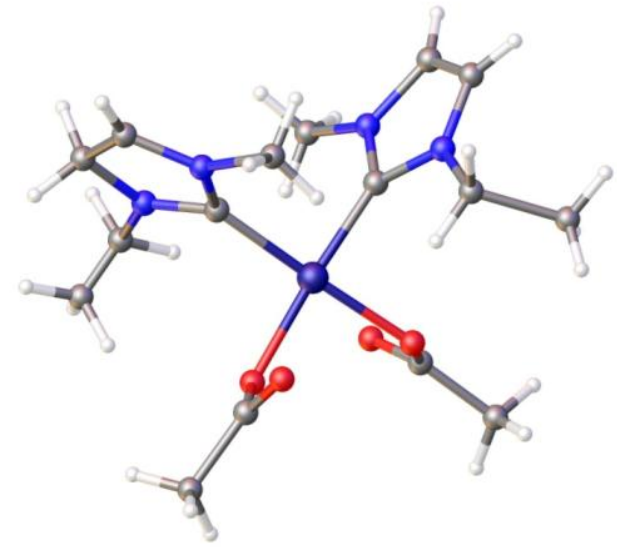

Figure 8: View of the crystal bis-(1-ethyl-3-methylimidazol-2-ylidene)diacetato-nickel(II).

\section{${ }_{50}$ Conclusions}

In this paper, the dissolution of the metal oxides $\mathrm{Ag}_{2} \mathrm{O}, \mathrm{NiO}, \mathrm{CuO}$ and $\mathrm{ZnO}$ has been investigated in several imidazolium ionic liquids without an additional solvent or additional base. It was found that carbene formation is the driving force behind the 55 dissolution process. New crystal structures of silver(I) and nickel(II) $N$-heterocyclic carbenes were determined. The speciation of the metal center was investigated by Raman and ${ }^{13} \mathrm{C}$ NMR spectroscopy. Stable zinc(II) carbenes were identified in these ionic liquids. The structure of the ionic liquid is of prime 60 importance for the dissolution process: this means that dissolution was only found for imidazolium ionic liquids with a hydrogen atom in the $\mathrm{C} 2$ position of the imidazolium ring, because only these ionic liquids can form carbenes by deprotonation of the $\mathrm{C} 2$ carbon. Neither in imidazolium ionic liquids with a methyl group 65 in the $\mathrm{C} 2$ position nor for ionic liquids with cations other than imidazolium dissolution of metal oxides was observed. The anion also plays a role, since carbene formation was observed for imidazolium ionic liquids with chloride, thiocyanate, dicyanamide and acetate anions, but not for 70 bis(trifluoromethylsulfonyl)imide anions.

\section{Acknowledgements}

This research was supported by the Flemish Institute for the Promotion of Innovation by Science and Technology (IWT ${ }_{75}$ Vlaanderen) via a Baekeland $\mathrm{PhD}$ fellowship to Sil Wellens (IWT 090272) and by Umicore Group Research. Support by IoLiTec (Heilbronn, Germany) is also gratefully acknowledged. The authors also thank the Hercules Foundation for supporting the purchase of an X-ray diffractometer through project 80 AKUL/09/0035. 


\section{Notes and references}

${ }^{a}$ KU Leuven, Department of Chemistry, Celestijnenlaan 200F, P.O. Box 2404, B-3001 Heverlee (Belgium)

E-mail: Koen.Binnemans@chem.kuleuven.be

$5^{b}$ Umicore, Group Research \& Development, Competence Area Recycling and Extraction Technologies, Kasteelstraat 7, B-2250 Olen (Belgium).

$\dagger$ Electronic Supplementary Information (ESI) available: [crystallographic information in CIF format]. See DOI: $10.1039 / \mathrm{b} 000000 \mathrm{x} /$

1. G. C. Tian, J. Li, and Y. X. Hua, T.Nonferr.metal soc., 2010, 20 , 513.

2. A. P. Abbott, G. Frisch, J. Hartley, and K. S. Ryder, Green Chem., 2011, 13, 471.

15 3. N. V. Plechkova and K. R. Seddon, Chem.Soc.Rev., 2008, 37, 123.

4. T. Welton, Chem.Rev., 1999, 99, 2071.

5. P. Wasserscheid and W. Keim, Angew.Chem., Int.Ed., 2000, 39, 3772 .

6. K. R. Seddon, J.Chem.Technol.Biotechnol., 1997, 68, 351.

7. A. Abbott, G. Frisch, S. Gurman, A. Hillman, J. Hartley, F. Holyoak, and K. Ryder, Chem.Commun., 2011, 47, 10031.

8. S. Dai, Y. S. Shin, L. M. Toth, and C. E. Barnes, Inorg.Chem., 1997, 36, 4900.

9. I. Billard, C. Gaillard, and C. Hennig, Dalton Trans., 20074214.

10. A. P. Abbott, G. Capper, D. L. Davies, R. K. Rasheed, and P. Shikotra, Inorg. Chem., 2005, 44, 6497.

11. A. P. Abbott, R. C. Harris, and K. S. Ryder, J.Phys.Chem.B, 2007, 111, 4910 .

12. P. Nockemann, B. Thijs, S. Pittois, J. Thoen, C. Glorieux, K. Van Hecke, L. Van Meervelt, B. Kirchner, and K. Binnemans, J.Phys.Chem.B, 2006, 110, 20978.

13. P. Nockemann, B. Thijs, T. N. Parac-Vogt, K. Van Hecke, L. Van Meervelt, B. Tinant, I. Hartenbach, T. Schleid, V. T. Ngan, M. T. Nguyen, and K. Binnemans, Inorg.Chem., 2008, 47, 9987.

14. A. J. Arduengo, H. V. R. Dias, J. C. Calabrese, and F. Davidson, Organometallics, 1993, 12, 3405.

15. C. Lee, C. S. Vasam, T. Huang, H. Wang, R. Yang, C. Lee, and I. J. Lin, Organometallics, 2006, 25, 3768.

16. J. C. Garrison and W. J. Youngs, Chem.Rev., 2005, 105, 3978.

17. I. J. B. Lin and C. S. Vasam, Comments Inorg.Chem., 2004, 25, 75.

18. J. C. Lin, R. T. Huang, C. S. Lee, A. Bhattacharyya, W. S. Hwang, and I. J. Lin, Chem.Rev., 2009, 109, 3561.

19. A. Kascatan-Nebioglu, M. J. Panzner, C. A. Tessier, C. L. Cannon, and W. J. Youngs, Coord.Chem.Rev., 2007, 251, 884.

20. I. J. Lin and C. S. Vasam, Coord.Chem.Rev., 2007, 251, 642.

21. A. C. Sentman, S. Csihony, R. M. Waymouth, and J. L. Hedrick, J.Org.Chem., 2005, 70, 2391.

22. C. Froschauer, K. Wurst, G. Laus, G. Nauer, and H. Schottenberger, Z.Kristallogr.- New Cryst.Struct., 2010, 225, 377.

23. U. Hintermair, U. Englert, and W. Leitner, Organometallics, 2011, 30, 3726.

24. CrysAlisPro. 2011. Yarnton, UK, Agilent Technologies. Ref Type: Computer Program

25. G. M. Sheldrick, Acta Cryst.A, 2008, 64, 112.

26. O. V. Dolomanov, L. J. Bourhis, R. J. Gildea, J. A. K. Howard, and H. Puschmann, J.Appl.Crystallogr., 2009, 42, 339.

27. H. M. J. Wang and I. J. B. Lin, Organometallics, 1998, 17, 972.

28. C. K. Lee, K. M. Lee, and I. J. B. Lin, Organometallics, 2002, 21 , 10.

29. I. J. B. Lin and C. S. Vasam, J.Organomet.Chem., 2005, 690, 3498.

30. D. A. Medvetz, K. M. Hindi, M. J. Panzner, A. J. Ditto, Y. H. Yun, and W. J. Youngs, Met.-Based Drugs, 2008, 1, 7.

31. J. C. Garrison, R. S. Simons, C. A. Tessier, and W. J. Youngs, J.Organomet.Chem., 2003, 673, 1 .

32. A. R. Chianese, B. M. Zeglis, and R. H. Crabtree, Chem.Commun., 20042176.

33. F. H. Allen, Acta Cryst.B, 2002, 58, 380.

34. J. M. Hayes, M. Viciano, E. Peris, G. Ujaque, and A. Lledos, Organometallics, 2007, 26, 6170.

35. O. Holloczki, D. S. Firaha, J. Friedrich, M. Brehm, R. Cybik, M. Wild, A. Stark, and B. Kirchner, J.Phys.Chem.B, 2013, 117, 5898.

36. J. P. Hallett, C. L. Liotta, G. Ranieri, and T. Welton, J.Org.Chem., 2009, 74, 1864.

37. M. Y. Lui, L. Crowhurst, J. P. Hallett, P. A. Hunt, H. Niedermeyer, and T. Welton, Chem.Sci., 2011, 2, 1491.

38. P. Gans, J. B. Gill, and D. P. Fearnley, J.Chem.Soc., Dalton Trans., 19811708

39. Kazuo Nakamoto, in Infrared and Raman Spectra of inorganic and coordination compounds, John Wiley \& sons, Inc., New York, 5 ed., 1997.

40. R. A. Bailey, S. L. Kozak, T. W. Michelse, and W. N. Mills, Coord.Chem.Rev., 1971, 6, 407.

41. S. Budagumpi and S. Endud, Organometallics, 2013, 32, 1537.

42. M. C. Law, K. Y. Wong, and T. H. Chan, Green Chem., 2004, 6, 241.

43. D. S. McGuinness, W. Mueller, P. Wasserscheid, K. J. Cavell, B. W. Skelton, A. H. White, and U. Englert, Organometallics, 2002, 21, 175

44. H. V. Huynh, C. Holtgrewe, T. Pape, L. L. Koh, and E. Hahn, Organometallics, 2006, 25, 245.

45. W. A. Herrmann, G. Gerstberger, and M. Spiegler, Organometallics, 1997, 16, 2209.

46. O. Holloczki and L. Nyulaszi, in Top. Curr. Chem., Springer Berlin Heidelberg, 2013, pp. 1-24.

47. T. Zell, T. Schaub, K. Radacki, and U. Radius, Dalton Trans., 2011, 40, 1852. 